\title{
UPAYA MENINGKATKAN PRESTASI BELAJAR SISWA SMP KELAS VIII PADA MATA PELAJARAN PENDIDIKAN AGAMA ISLAM DENGAN PEMBELAJARAN TIPE JIGSAW
}

\author{
LUKITO \\ SMP Negeri 10 Balikpapan, Kalimantan Timur \\ e-mail : muhdhorilukito@gmail.com
}

\begin{abstract}
ABSTRAK
Upaya meningkatkan Prestasi Belajar Siswa SMP Kelas VIII Pada Mata Pelajaran Pendidikan Agama Islam Model Pembelajaran Tipe Jigsaw di SMP Negeri 10 Balikpapan Tahun Ajaran 2018-2019. Penelitian ini adalah penelitian tindakan kelas yang bertujuan untuk meningkatkan prestasi belajar Siswa SMP Negeri 10 Balikpapan kelas VIII-I dengan model pembelajaran tipe jegsaw. Subjek penelitian ini adalah siswa kelas VIII-I SMP Negeri 10 Balikpapan sebanyak 32 peserta didik. Alat pengumpul data yang digunakan berupa lembar observasi dan tes objektif pilihan ganda biasa, berdasarkan hasil observasi pada tindakan siklus I dan siklus II terdapat peningkatan prestasi siswa. Secara umum diperoleh $88,09 \%$ siswa pada siklus I dan $91,63 \%$ pada siklus II. Peningkatan prestasi belajar ini terjadi dikarenakan setiap siswa mendiskusikan pembagian anggota kelompoknya ke dalam kelompok ahli berdasarkan pengarahan guru, demikian pula pada kelompok asal diskusi siswa antusias untuk mempresentasikan hasil diskusi. Selanjutnya didapatkan pada peningkatan hasil belajar yang tampak pada kreteria indeks gain tiap siswa yaitu 12 siswa sedang dan 20 siswa tinggi pada siklus I menjadi 8 siswa sedang, 24 siswa tinggi pada siklus II
\end{abstract}

Kata Kunci : Prestasi Belajar, Pembelajaran Kooperatif, Model Tipe Jigsaw

\section{ABSTRACT}

Efforts to improve the learning achievement of $8^{\text {th }}$ grade junior high school students in Islamic religious education subject's jigsaw type learning model at SMP 10 Balikpapan for the 20182019 school year. This research is classroom action research that aims to improve the learning achievement of $8^{\text {th }}$ grade junior high school student at SMP 10 Balikpapan with a jigsaw type learning model. The subject of this research are students of class 8-I at SMP 10 Balikpapan as many as 32 students. Data collection tolls used in the form of observation sheets and ordinary multiple choice objective tests, based on the result of observation in the actions of cycle I and cycle IIthere was an increase in student achievement. Generally, obtained 88,09\% of students in cycle I and $91,63 \%$ of students in cycle II. This increase in learning achievement occurs because each student discusses the division of his group into expert groups based on the teacher's direction. Likewise, in the group from which the discussion originated, students were enthusiastic to present the result of the discussion. Furthermore, it was found that increase in learning outcomes was seen in the gain index criteria for each student, there are 12 moderate students and 20 high students in cycle I to 8 moderate students, 24 high students in cycle II.

Keyword: Learning achievement, cooperative learning, jigsaw type model.

\section{PENDAHULUAN}

Pembelajaran Pendidikan Agama Islam (PAI) tidak hanya lebih dari sekedar fakta, konsep dan hapalan, tetapi semestinya menyentuh juga sisi dari proses rekonstruksi berpikir dan belajar yang terjadi dalam diri siswa. Oleh karena itu pembelajaran perlu dirancang sedemikian rupa hingga mampu menciptakan suasana interaktif, iklim kelas yang kondusif untuk mencapai tujuan pembelajaran Pendidikan Agama Islam (PAI), dan menumbuhkan kepedulian, kepekaan sekaligus membangun siswa menjadi seorang yang berintelektual tinggi dengan pengetauan agama yang bsa memadukan anatara aqli dan naqli. Oleh sebab itu, beban yang diemban oleh sekolah, dalam hal ini adalah guru sangat berat, karena guru PAI memilki tanggung jawab yang besar dalam membentuk pribadi peserta didik. 
Permasalahan mengenai pembelajaran PAI yaitu sulitnya guru menyampaikan materi PAI menjadi menarik bagi siswa. Hal ini menyebabkan kualitas hasil belajar mata pelajaran PAI kurang memuaskan, sehingga guru terdorong untuk melakukan suatu perubahan baik dalam teknik mengajar maupun pengelolaan kelas. Saat ini di SMP Negeri10 Balikpapan, khususnya guru masih mengutamakan target ketuntasan materi ajar dibandingkan proses belajar yang terjadi pada siswa, sehingga guru hanya berperan sebagai transformator (menyampaikan materi) kepada siswa.

Hal ini menyebabkan pemilihan metode mengajar konvensional sebagai alternatif terbaik yang digunakan dalam proses pembelajaran. Salah satu metode konvensional yang sering digunakan yaitu diskusi.

Pembelajaran dengan menggunakan metode diskusi, kurang menimbulkan interaksi di antara siswa, kegiatan diskusi lebih didominasi oleh siswa yang pandai saja. Dengan demikian informasi mengenai konsep yang disampaikan guru hanya dapat dipahami siswa pandai saja. Berdasarkan kondisi tersebut maka diperlukan suatu metode diskusi yang dapat menciptakan proses interaksi positif di antara siswa.

Metode pembelajaran sebagai cara dalam menyajikan (menguraikan, memberi contoh dan memberikan pelatihan), isi pembelajaran kepada siswa untuk mencapai kompetensi tertentu. Keberhasilan dari suatu pembelajaran sangat dipengaruhi oleh metode pembelajaran yang digunakan. Selain metode, model pembelajaranpun bisa dijadikan alternatif untuk memperbaiki proses belajar mengajar di kelas. Model pembelajaran yang dapat mengembangkan aktifitas siswa salah satunya adalah model kooperatif learning ( pembelajaran kooperatif ).

Memilih suatu model mengajar, harus disesuaikan dengan realitas yang ada dan situasi kelas yang ada serta sasaran yang akan dihasilkan dari proses kerjasama yang dilakukan antara guru dan peserta didik. Dengan demikian, seorang guru harus mampu menentukan model mengajar mana yang akan dipilih dalam menyampaikan suatu materi, agar para peserta didik dapat dengan mudah menyerap apa yang disampaikannya. Berdasarkan masalah yang ditemukan di SMP Negeri 10 Balikpapan kelas VIII-I , model kooperatif tipe jigsaw, cukup relevan untuk mengatasi permasalahan ini. Menurut (Lie A., 2007), pembelajaran kooperatif memberikan kesempatan kepada siswa untuk berinteraksi dan bekerja sama dengan siswa yang lain dalam suasana gotong royong yang harmonis dan kondusif, sedangkan menurut Johnson \& Johnson (Kurniawati, 2006) pembelajaran kooperatif merupakan suatu pendekatan yang humanistik. Strategi belajar yang seperti ini layak dipilih oleh guru, sebab merupakan wahana potensial bagi berkembangnya interaksi positif yang mampu mewujudkan iklim kelas ideal.

Berdasarkan kajian penelitian tentang pembelajaran kooperatif jigsaw yang sudah ada (Kurniawati, 2006), lebih terfokus pada keefektifan pembelajarannya dalam kegiatan diskusi yang dilihat dari hasil pencapaian belajar. Hasil penelitian tentang proses-proses yang terjadi saat pembelajaran.

Dengan model tersebut menunjukkan adanya aktifitas siswa yang positif. Selain aktivitas siswa, ada hal lain yang membentuk iklim kelas menjadi kondusif, yaitu interaksi siswa. Interaksi siswa juga menentukan keberhasilan suatu kegiatan pembelajaran.

Materi yang menjadi pilihan peneliti dalam penelitian ini adalah materi mengenai Imann kepada kitab kitab Allah.. merupakan konsep yang cukup kompleks, dan cukup luas bahasannya, sehingga siswa sulit untuk memahaminya. Diperlukan usaha membaca atau literasi bagi siswa.

Tujuan yang ingi dicapai dalam Penelitian Tindakan Kelas ini adalah meningkatkan prestasi belajar siswa melalui model pembelajaran kooperatif tipe jigsaw. Selan itu juga untuk memperoleh informasi mengenai hasil prestasi pada tahapan-tahapan pembelajaran kooperatif tipe jigsaw.

Dengan melakukan Penelitian Tindakan Kelas di SMP Negeri 10 Balikpapan yang berjudul, Upaya Meningkatkan Prestasi Belajar Siswa SMP Kelas VIII pada Mata Pelajaran Pendidikan Agama Islam dengan Model Pembelajaran Type Jigsaw, maka bisa diambil 
manfaat untuk siswa dan guru. Bagi siswa dapat menanamkan pembelajaran positif antara siswa dalam kegiatan pembelajaran di kelas. Siswa yang pintar, bisa membantu siswa yang kurang dengan cara berinteraksi dalam pembelajaran. Siswa yang kurang juga bisa termotivasi belajarnya, karena pengaruh keerikatan kelompok untuk menyelesaikan tugas bersama. Bagi guru bisa sebagai salah satu solusi dalam meningkatkan pembelajaran siswa pada saat kegiatan pembelajaran di dalam kelas dan memotivasi guru untuk melakukan penelitian tindakan kelas bersama.

Menurut Rustaman et. Al (2005) belajar kooperatif merupakan suatu teknik pembelajaran yang membentuk siswa dalam kelompok kecil dengan anggota 4-5 orang. Dengan teknik belajar secara kooperatif ini akan terjadi interaksi sesama anggota kelompok. Semua anggota kelompok dituntut terlibat secara langsung, karena keberhasilan kelompok ditunjang oleh keaktifan anggotanya, sehingga anggota kelompok saling membantu.

Menurut Piaget, (1989) pertukaran gagasan-gagasan tidak dapat dihindari untuk perkembangan penalaran. Walaupun penalaran ini tidak dapat diajarkan secara langsung, perkembangannya dapat distimulasi oleh konfrontasi kritis, khususnya dengan teman-teman setingkat. Seperti hal perbedaan pendapat itu esensial untuk konstruksi sains, demikian pula hal ini tidak dapat dihindari untuk mengkonstruksi pengetahuan pisik dan logika - matematika. Menurut Piaget, para siswa hendaknya para siswa mempunyai pendapat sendiri, mengemukakannya, mempertahankannya, dan merasa bertanggung jawab atasnya. Ungkapan secara jujur, akhirnya memupuk ekuilibrasi konstruksi dan membuat para siswa lebih cerdas dan lebih termotivasi untuk terus belajar.

Menurut Lie (2007) guru yang ingin maju dan berkembang perlu mempunyai persediaan strategi dan metoda-metoda pembelajaran yang pasti akan selalu bermanfaat dalam melaksanakan kegiatan belajar mengajar sehari-hari. Guru bisa memilih dan memodifikasi sendiri sesuai dengan kondisi kelas. Salah satu metoda yang dapat digunakan adalah metode pembelajaran kooperatif tipe Jigsaw.

Tinjauan dari Pendidikan Agama Islam (PAI) adalah agama memiliki peran yang sangat penting dalam kehidupan umat manusia. Agama menjadi pemandu atau petunjuk dalam upaya seseorang dalam upaya mewujudkan suatu kehidupan yang memiliki makna, damai dan bermartabat. Tentunya mencapai kebahagiaan di dunia sampai akherat. Allah berfirman dalam Al-Qur'an/3:19

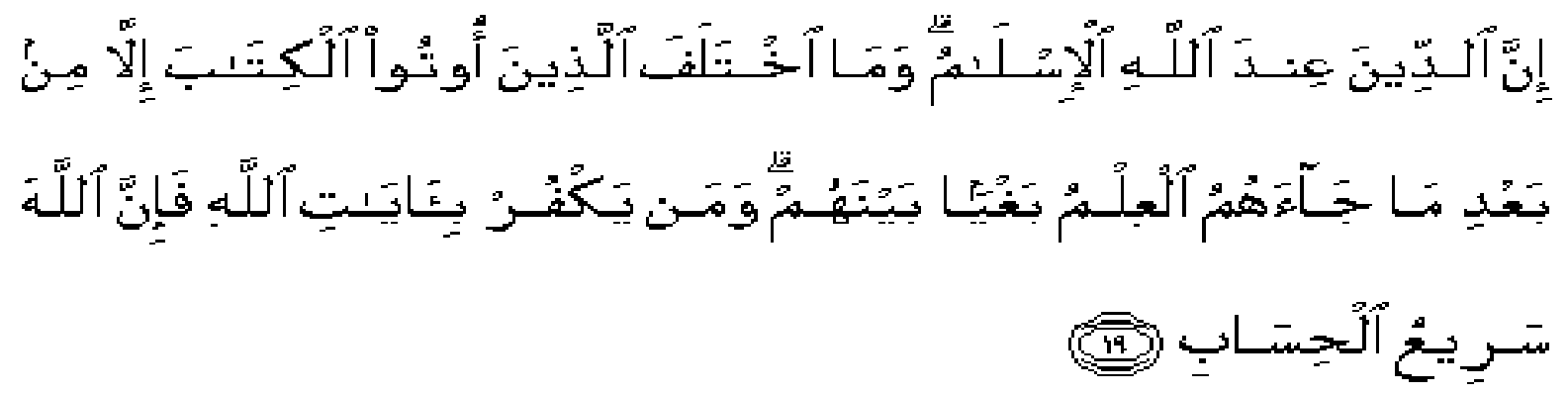

Artinya: " sesunguhnya agama yang diridhoi oleh Allah hanyalah agama Islam. Tiada berselisih orang orang yang diberi kitab, kecuali setelah mereka memperoleh ilmu, karena kedengkian diantara mereka. Barang siapa yang ingkar terhadap ayat-ayat Allah, maka sungguh Allah sangat cepat perhitungan Nya.".(Q.S.Al Imron/3:19). Ayat ini dijadikan dalil naqli dalam pelaksanaan proses pembelajaran Pendidikan Agama Islam.

Pendidian Agama Islam diberikan di sekolah diharapkan menghasilkan peserta didik yang selalu berupaya menyempurnakan iman, taqwa, dan akhlak atau budi pekerti yang luhur. Pendidikan Agama Islam di sekolah juga dimaksudkan untuk meningkatkan moral dan spiritual yang mencakup pengenalan, pemahaman, penanaman, dan pengamalan nialai - nilai agama Islam dalam kehidupan peserta didik di sekolah maupun di masyarakat. 
Pada diktat Pendalaman Materi Pendidikan Agama Islam Sekolah Menengah Pertama (SMP) oleh LPTK Fakultas Tarbiyah IAIN Antasari Banjarmasin 2012. Tertulis bahwa ada beberapa karekterisitik mata pelajaran PAI untuk Sekolah Menengah Pertama seperti PAI merupakan rumpun pelajaran yang dikembangkan dari ajaran pokok yang terdapat dalam agama Islam. Tujuan PAI adalah terbentuknya peserta didik yang beriman dan bertaqwa kepada Allah Swt. berbudi pekerti yang luhur (berakhlak mulia), memiliki pengetahuan tentang ajaran pokok agama Islam dan mengamalkannya dalam kehidupan sehari-hari.

Pembelajaran Kooperatif Tipe Jigsaw merupakan salah satu tehnik yang digunakan dalam metode cooperative learning. Elliot Aronson pertama kali menggunakan tehnik ini bersama dengan muridnya pada tahun 1971 di Austin, Texas. Pada tehnik Jigsaw dilakukan pengelompokan siswa antara 5 sampai 6 orang, dimana setiap siswa dalam satu kelompok memiliki potongan materi yang berbeda, yang kemudian mendiskusikannya. Keunikan tehnik Jigsaw ialah adanya kelompok ahli yang merupakan kelompok siswa yang membahas potongan materi yang sama, setelah siswa berdiskusi dengan kelompok awal selanjutnya dibentuk kelompok ahli dan pada akhirnya kembali pada kelompok awal untuk memberikan informasi tambahan mengenai tiap potongan materi.

Penggunaan tehnik Jigsaw membantu siswa untuk berinteraksi dalam memahami materi tertentu. Roger dan David Johnson (1996), memberikan pengertian tentang metode kooperatif learning tipe Jigsaw yaitu, metode yang bersifat kelompok dimana dituntut adanya kerjasama tim dan tanggung- jawab setiap anggota dalam mengerjakan tugas-tugasnya yang sifatnya terstruktur. Selain itu, Elliot Aronson (2000), menjelaskan kelebihan tehnik Jigsaw, yaitu; 1) Kebanyakan guru dapat dengan mudah menerapkan tehnik Jigsaw. 2) Guru menikmati penerapan tehnik Jigsaw dalam kelas. 3) Tehnik Jigsaw dapat digunakan bersama strategi belajar yang lain. 4) Dapat diterapkan sekalipun satu jam pelajaran.

\section{METODE PENELITIAN}

Penelitian Tindakan Kelas ini dilakukan dengan menggunakan desain model Kemmis dan Mc Taggart (1997). Mulai dari Masalah $\rightarrow$ Rencana awal $\rightarrow$ Tindakan/Observasi $\rightarrow$ Refleksi $\rightarrow$ Rencana yang direvisi $\rightarrow$ Tindakan/Siklus I $\rightarrow$ Refleksi $\rightarrow$ Rencana yang direvisi $\rightarrow$ Tindakan/Siklus II $\rightarrow$ Refleksi $\rightarrow$ Kesimpulan.

Untuk menganalisis tingkat keberhasilan atau presentase keberhasilan siswa setelah proses pembelajran berlangsung dari setiap putaran, maka dilakukan dengan memberikan evaluasi. Evaluasi diberikan dengan memberikan soal-soal tes tertulis pada setiap akhir putaran. Dalam menghitung analisis data yang menyangkut data kuantitatif , maka digunakan statistik sederhana. Kemudian untuk data kualitatif adalah memberikan penilaian dari catatan kegiatan observasi lapangan. Data kualitatif diinterpretasikan secaara diskriptif pada setiap pertemuan dan setiap siklus yang kemudian akan dijadikan sebagai bahan refleksi siklus.

\section{HASIL DAN PEMBAHASAN}

Pada bab IV ini akan dideskripsikan tentang pelakasanaan, pembahasan dan hasil penelitian tindakan kelas yang telah dilakukan pada masing masing siklus dimulai siklus I sampai dengan siklus II, maupun hasil analisis tindakan pada saat observasi awal pembelajaran

\section{Analisis Data Penelitian Persiklus}

Tabel 1 : Hasil tes dengan 10 soal

\begin{tabular}{|l|l|l|l|l|l|l|l|}
\hline \multirow{2}{*}{ NO } & \multirow{2}{*}{ NAMA } & \multicolumn{2}{|c|}{ Pre Tes } & \multicolumn{2}{c|}{ Siklus I } & \multicolumn{2}{c|}{ Siklus II } \\
\cline { 3 - 8 } & & Nilai & Kategori & Nilai & Kategori & Nilai & Kategori \\
\hline 1. & Ade Indra & 60 & TL & 60 & TL & 70 & TL \\
\hline 2. & Adna Aprilia & 60 & TL & 60 & TL & 100 & T \\
\hline 3. & Adrian & 70 & TL & 80 & T & 90 & T \\
\hline
\end{tabular}


ACTION : Jurnal Inovasi Penelitian Tindakan Kelas dan Sekolah

Vol 2. No 1. Januari 2022 e-ISSN : 2798-5733 P-ISSN : 2798-5741

\begin{tabular}{|l|l|l|l|l|l|l|l|}
\hline 4. & Anastasia & 60 & TL & 80 & T & 90 & T \\
\hline 5. & Ayu Marisa & 70 & TL & 70 & TL & 100 & T \\
\hline 6. & Dera S. & 60 & TL & 60 & TL & 90 & T \\
\hline 7. & Deviana S. & 70 & TL & 80 & T & 100 & T \\
\hline 8. & Diana Putri & 70 & TL & 80 & T & 90 & T \\
\hline 9. & Dedi Adam & 70 & TL & 80 & T & 90 & T \\
\hline 10. & Eric Prabowo & 60 & TL & 80 & T & 90 & T \\
\hline 11. & Ernayanti & 70 & TL & 70 & TL & 90 & T \\
\hline 12. & Evi N. & 70 & TL & 80 & T & 90 & T \\
\hline 13. & Faisal & 60 & TL & 70 & T & 70 & TL \\
\hline 14. & M. Awad J. & 60 & TL & 80 & T & 90 & T \\
\hline 15. & M. ahnaf & 60 & TL & 80 & T & 90 & T \\
\hline 16. & M. Reno & 60 & TL & 60 & TL & 90 & T \\
\hline 17. & Muh. Adi & 60 & TL & 80 & T & 90 & T \\
\hline 18. & Nurul Hazizah & 70 & TL & 80 & T & 90 & T \\
\hline 19. & Rahmat Hidayat & 60 & TL & 70 & TL & 90 & T \\
\hline 20. & Rahman Y. & 70 & TL & 70 & TL & 90 & T \\
\hline 21. & Reva A. & 80 & T & 80 & T & 90 & T \\
\hline 22. & Rostanti & 60 & TL & 80 & T & 100 & T \\
\hline 23. & Sabrina A. & 60 & TL & 60 & TL & 90 & T \\
\hline 24. & Sadam Nur & 60 & TL & 80 & T & 80 & T \\
\hline 25. & Salma Okta & 50 & TL & 50 & TL & 90 & T \\
\hline 26. & Saparuddin & 60 & TL & 70 & TL & 70 & TL \\
\hline 27. & Septiana & 60 & TL & 70 & TL & 100 & T \\
\hline 28. & Tania & 50 & TL & 60 & TL & 90 & T \\
\hline 29. & Waili Sari & 70 & TL & 80 & T & 90 & T \\
\hline 30. & Widjaya S. & 70 & TL & 80 & T & 80 & T \\
\hline 31. & Zakaria & 70 & TL & 80 & T & 90 & T \\
\hline 32. & Zalfa Mareta & 70 & TL & 80 & T & 90 & T \\
\hline & & & & & & \\
\hline 20 & & & & & & \\
\hline
\end{tabular}

Hasil Tes Siklus I, Terdapat kenaikan dalam hal ketuntasan belajar peserta didik. Dibandingkan hasil pre tes. Penggunaan alat peraga sederhana pengelompokan belajar dapat membantu peserta didik dalam meningkatkan minat dan hasil belajar. Tetapi hasil belajarnya rata- rata belum menunjukkan tingkat pemahaman yang baik.

\section{Pembahasan Siklus Kedua}

Selanjutnya, untuk pelaksanaan Tes, digunakan tes bentuk pilihan ganda mengadopsi dari tes pada Siklus I. Untuk Siklus II ini tetap menggunakan 10 soal sesuai dengan waktu yang direncanakan.

Dalam Siklus II ini, Kegiatan Belajar Mengajar berjalan sesuai dengan rencana. Semua anggota kelompok menikmati tugas diskusi kelompok. Ketika terjadi kesulitan kemudian peserta didik tidak segera menemukan jawabannya, Tim Ahli sebagian besar berhasil mengorganisir anggotanya. Hanya sayangnya ketika disuruh untuk mempresentasikan hasil kerjannya, kebanyakan belum mampu. Sehingga diputuskan hasil kerja kelompok tersebut ditempel di dinding kelas untuk bisa dilihat temannya yang lain anggota. 
Dari hasil Tes Siklus II , ada kenaikan dalam hal ketuntasan belajar peserta didik. Kenaikan nilai tes yang dicapai peserta didik, sangat signifikan dibandingkan dengan ketuntasan belajar yang terjadi pada siklus I. Nilai tes yang dicapai peserta didik dalam Siklus II banyak yang masuk kategori terlampaui. Ini menunjukkan bahwa perubahan soal dari penggunaan model pembelajaran koperatif jigsaw dan alat peraga sederhana dari Sikulus I dengan Siklus II dapat membantu peserta didik meningkatkan minat dan hasil belajar. Yang pada akhirnya kembali kepada niat guru, punya kemauan atau tidak untuk mencari model pembelajaran yang cocok dengan kareaterisitik peserta didik dan mengikhtiarkan kebiasaan menggunakan alat peraga dalam setiap Kegiatan Belajar Mengajar. Meskipun alat peraga itu sangat sederhana, tetapi tentunya akan membantu pelaksanaan proses pemahaman dalam menangkap pembelajaran pada peserta didik. Begitu juga dengan pemilihan model pembelajaran, akan sangat membantu proses pelaksanaan kegiatan belajar mengajar ( KBM ) dapat berhasil dengan baik

\section{Analisis Per Siklus}

Rekapitulasi observasi pada kegiatan Belajar Mengajar ( $\mathrm{KBM}$ ) yang dilakukan pada pertemuan kedua dapat dilihat pada tabel berikut ini.

Tabel 2. Rekapitulasi observasi KBM Siklus II.

\begin{tabular}{|l|c|c|c|c|}
\hline \multirow{2}{*}{ KBM } & \multicolumn{2}{|c|}{ Siklus I } & \multicolumn{2}{c|}{ Siklus II } \\
\cline { 2 - 5 } & $\begin{array}{c}\text { Presentase } \\
\text { Nilai }\end{array}$ & Keterangan & $\begin{array}{c}\text { Presentase } \\
\text { Nilai }\end{array}$ & Keterangan \\
\hline Kegiatan Awal & $60 \%$ & $\begin{array}{c}\text { Terkendala } \\
\text { kesiapan siswa }\end{array}$ & $90 \%$ & Lancar \\
\hline Kegiatan Inti & $60 \%$ & Terkendala buku & $85 \%$ & Lancar \\
\hline $\begin{array}{l}\text { Kegiatan } \\
\text { Akhir }\end{array}$ & $80 \%$ & Lancar & $90 \%$ & Lancar \\
\hline
\end{tabular}

Berdasarkan rekapitulasi dari table 2, pelaksanaan Siklus II secara umum berjalan dengan baik dan sangat lancar. Pada Siklus I, Kendala dalam Kegiatan Belajar Mengajar langsung disampaikan titik lemahnya kepada peserta didik. Terutama kendala teknis ketiadaan buku referensi yang menunjang pembelajaran. Peserta didik yang menjadi sumber kegaduhan pada Siklus I dapat dimaksimalkan untuk beraktifitas dengan baik dalam tugas kerja bersama kelompoknya.

Dilihat dari hasil capaian prestasi belajar peserta didik dalam Siklus I belum menunjukkan keberhasilan ketuntasan belajar mencapai. Hasilnya tidak sampai 60 $\%$. Untuk lebih mengetahui efek atau pengaruh dari setrategi pembelajaran yang sudah dilakukan, maka peserta didik sudah diwanti wanti diisyaratkan bahwa aka nada tes kedua sebagai tes remedial yang nilainya kemarin pda pertemuan pertama masih belum tuntas. Semua peserta didik harus mengikuti tes tersebut. Yang sudah tuntas pada pertemuan pertama dijadikan untuk tambahan nilai, ata sebagai pengayaan.

Waktu yang dipakai untuk post tes sekitar 15 menit. Cukup untuk mengerjakan soal pilihan ganda yang sudah disiapkan dengan jumlah tes 10 soal. Soal Tes pada siklus II diambilkan dari soal-soal yang diberikan pada Siklus I.

Hasil tes menunjukkan bahwa dari 32 peserta didik kelas VIII-I, ada 29 peserta didik berhasil menuntaskan pembelajaran dengan predikat terlampaui. Sedangkan 4 peserta didik belum mampu mencapai KKM. 3 peserta didik berhasil memperoleh nilai 80. 21 peserta didik memperoleh nilai 90, kemudian 4 peserta didik dapat memperoleh nilai sempurna 100 . 


\section{Refleksi siklus}

Pelaksanaan Siklus II tidak menemui hambatan yang sulit, seperti yang terjadi pada proses pembelajaran di Siklus I. Proses pembelajaran pada Siklus II berlangsung dengan lancar, tertib dan terkendali, sesuai dengan rencana pembelajaran. Jika ada peserta didik yang belum mampu dalam mencapai KKM, maka dalam hal ada masalah menyangkut kesulitan belajar. Diperlukan tindakan untuk melakukan remedial atau pengulangan. Tindakan pengayaan diberikan juga kepada peserta didik yang sudah mencapai ketuntasan belajar. Untuk mendamingi ketika temannya yang perlu remedial.

Pada pelaksanaan Siklus II diperoleh peningkatan hasil belajar yang memuaskan. Terutama dalam hasil nilai belajar peserta didik yang kenaikannya sangat signifikan dibandingkan pada hasil belajar siklus I. Ketuntasan belajar peserta didik pada Siklus II mencapai $90.62 \%$.

Dari pelaksanaan persiklus ini dapar diperoleh refleksi atau tolak ukur untuk pengawasan pembelajaran pada guru, Untuk lebih optimal lagi dengan kegiatan pembelajaran. Model pembelajaran dengan Koperatif model jigsaw, membutuhkan pengawasan yang ketat peserta didik dalam bekerja atau berperan dalam kelompoknya. Terutama mengoptimalkan pada Tim Ahli dari peserta didik yang ditunjuk.Jangan sampai tugas kerja kelompok, tetapi yang mengerjakan tugas hanya satu anak atau beberapa peserta kelompok saja. Sedangkan yang lainnya malahan ngobrol, Begitu juga, Guru harus menegur terhadap peserta didik yang lepas dari kelompoknya.

\section{Analisis Penelitian}

Secara keseluruhan, Penelitian Tindakan Kelas ini dapat dianalisis berdasarkan distribusi hasil belajar peserta didik. Seperti pada tabel dibawah ini. Kolom rentang merupakan kelompok rentang nilai yang diperoleh peserta didik. Kolom rentang, kolom pra (\%), kolom Siklus I (\%), dan kolom Siklus II (\%). Masing-masing menunjukkan jumlah peserta didik pada rentang nilai tertentu yang digambarkan dalam persen $(\%)$

Tabel 3. Distribusi Hasil Belajar Siswa

\begin{tabular}{|l|l|l|l|l|}
\hline No. & Rentang & Pra $\%$ & Siklus I\% & Siklus II \% \\
\hline 1. & $0-10$ & $0 \%$ & $0 \%$ & $0 \%$ \\
\hline 2. & $11-20$ & $0 \%$ & $0 \%$ & $0 \%$ \\
\hline 3. & $21-30$ & $0 \%$ & $0 \%$ & $0 \%$ \\
\hline 4. & $31-40$ & $0 \%$ & $0 \%$ & $0 \%$ \\
\hline 5. & $41-50$ & $6.25 \%$ & $3.13 \%$ & $0 \%$ \\
\hline 6. & $51-60$ & $50 \%$ & $18.75 \%$ & $0 \%$ \\
\hline 7. & $61-70$ & $40.63 \%$ & $21.88 \%$ & $9.36 \%$ \\
\hline 8. & $71-80$ & $3.13 \%$ & $56.25 \%$ & $9.36 \%$ \\
\hline
\end{tabular}




\begin{tabular}{|l|l|l|l|l|}
\hline 9. & $81-90$ & $0 \%$ & $0 \%$ & $65.62 \%$ \\
\hline 10. & $91-100$ & $0 \%$ & $0 \%$ & $12.50 \%$ \\
\hline
\end{tabular}

Untuk menunjukkan hasil rentang nilai belajar peserta pada setiap siklus, maka dibawah ini tergambar grafik rentang nilai hasil belajar peserta didik pada pre tes, siklus I dan siklus II.

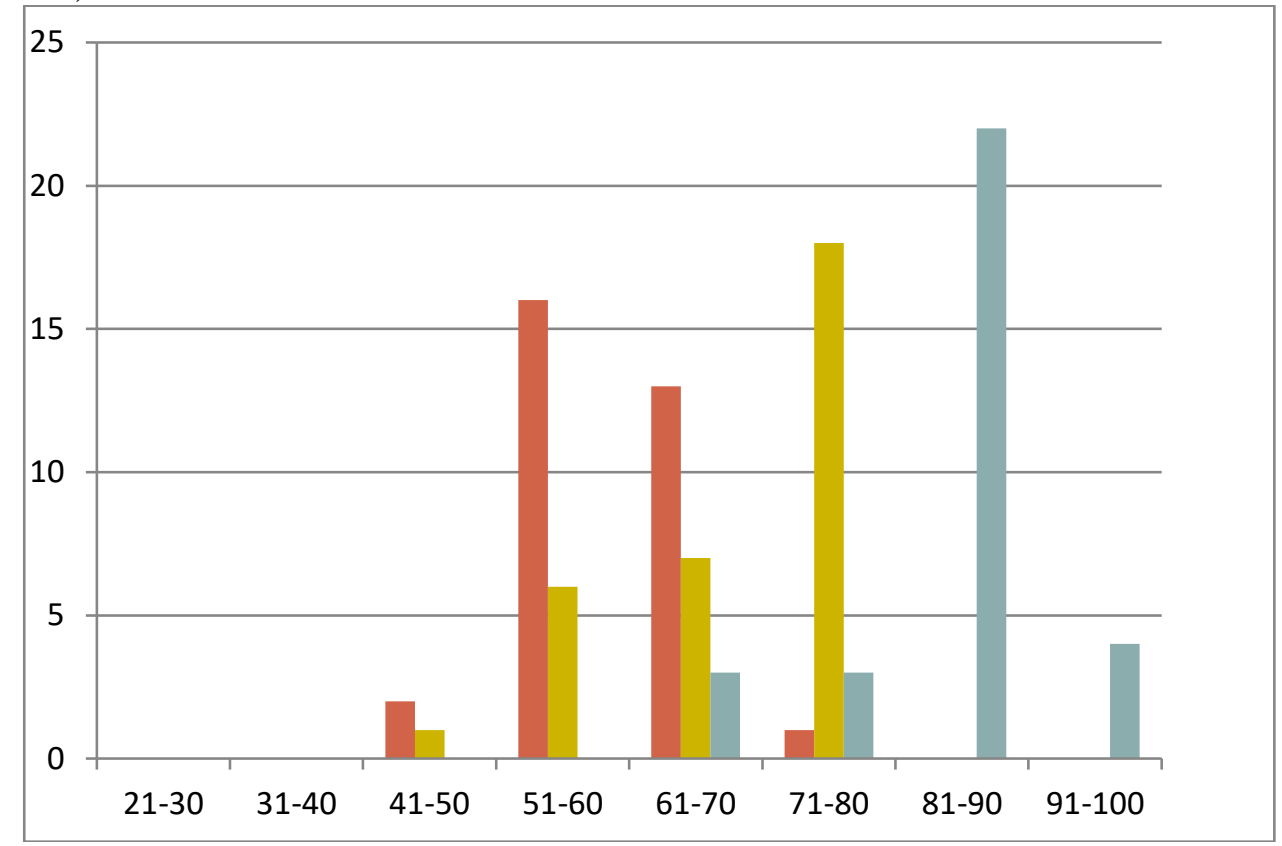

Gambar 1. Grafik Rentang nilai

Ket. : warna merah untuk pre tes warna kuning untuk siklus I. warna biru untuk siklus II

Batang warna merah untuk pre tes menunjukkan nilai sebagian besar dari peserta didik kurang dari 70. Sedangkan batang kuning untuk siklus I menunjukkan peningkatan nilai yang mana sebagian besar peserta didik bisa meraih di atas 70 . Batang biru hasil dari siklus II yang bisa mencapai ketuntasan $85 \%$ lebih

Untuk menunjukkan hasil ketuntasan belajar peserta pada setiap siklus, maka dibawah ini tergambar grafik ketuntasan hasil belajar peserta didik pada siklus I dan siklus II. Dari menganilisis grafik di bawah ini terlihat jelas keberhasilan proses kegiatan belajar mengajar peserta didik pada pelaksanaan siklus II.

Untuk menunjukkan hasil ketuntasan belajar peserta pada setiap siklus, maka dibawah ini tergambar grafik ketuntasan hasil belajar peserta didik pada siklus I dan siklus II. Dari menganilisis grafik di bawah ini terlihat jelas keberhasilan proses kegiatan belajar mengajar peserta didik pada pelaksanaan siklus II. 


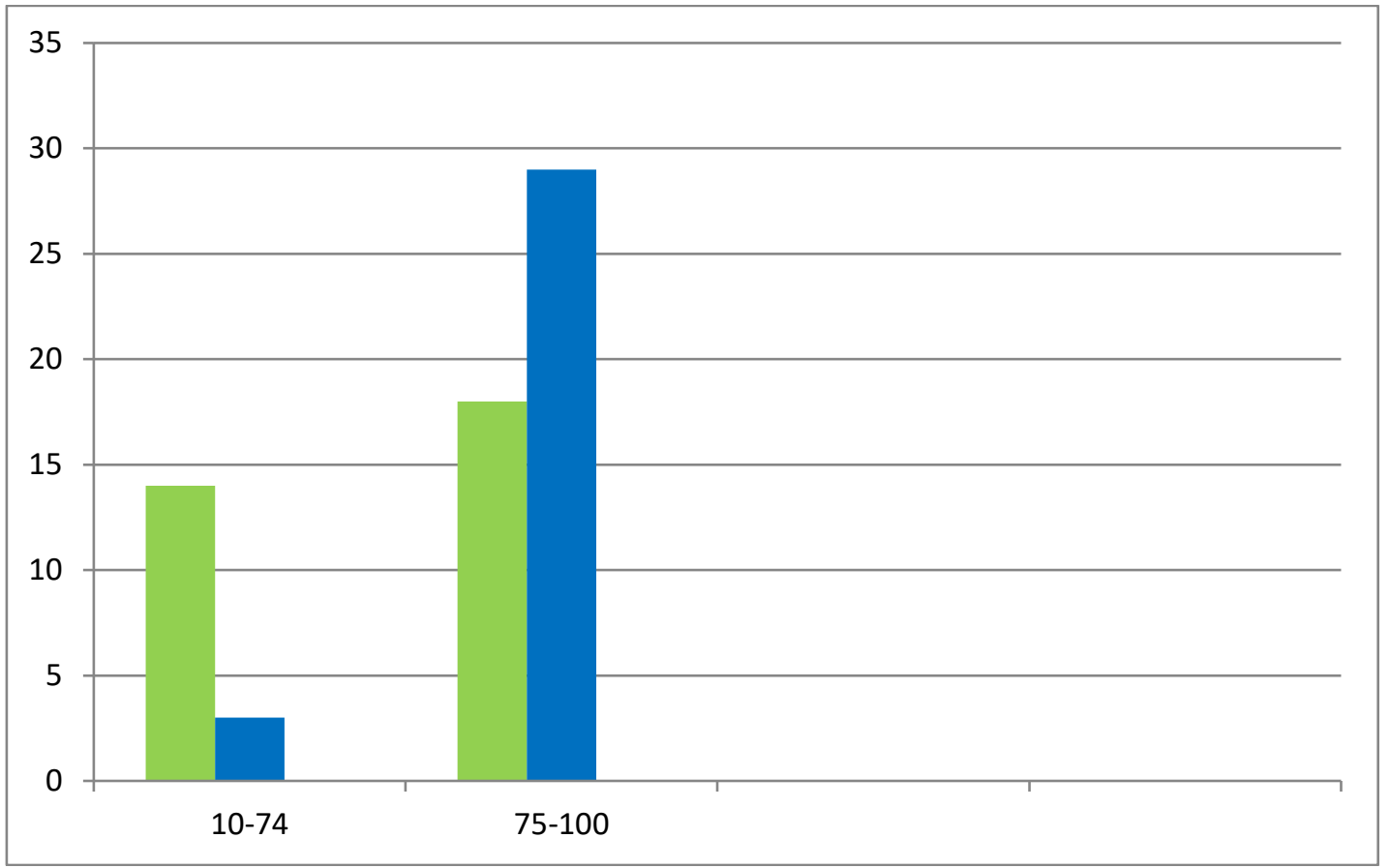

Gambar 2. Grafik ketuntasan belajar peserta didik

Keterangan ; Warna hijau tidak tuntas warna biru tuntas atau terlampaui

Batang hijau pada siklus I pertama menunjukan belum ada peningkatan yang signifikan dari hasil belajar pada sebagaian besar peserta didik. Sedangkan batang warna biru untuk siklus II menunjukkan peningkatan besar pada nilai hasil belajar peserta didik, karena telah berhasil mencapai KKM (Kriteria Kutuntasan Minimal) untuk mata pelajaran Pendidikan Agama Islam di SMP Negeri 10 Balikpapan. Ada 3 peserta didik yang belum bisa mendapatkan nilai di atas KKM, sehingga perlu tindakan remedial.

Secara umum Penelitian berlangsung lancar dan sukses. Terdiri dari 2 pertemuan dan 2 siklus. Kendala yang terlihat pada Pertemuan I adalah jawaban Lembar Kerja tugas kelompok tidak ada di buku paket yang dipegang siswa, sehingga harus meminjam buku paket yang lain di perpustakaan. Kemudian Tim ahli belum bisa menunjukkan kemampuannya dalam mengkordinir anggotanya. Dari kedua kendala tersebut selanjutnya untuk persiapan Pertemuan II, Tim ahli bisa membawa buku paket yang dipinjam di perpustakaan. Tim ahli dikumpulkam tersendiri dan diberi motivasi untuk bisa percaya diri dalam menkordinir anggotanya. Untuk Pertemuan II, kendala yang ada tidak terlalu menforsir aktifitas guru, karena sudah diantisipasi sebelumnya. Peserta didik dapat menikmati pembelajaran, meskipun pada Lembar Kerja Tugas ditambah dua kolom berupa isi kitab dan dalil kitab. Selain dua referensi buku paket, ada beberapa peserta didik yang mempunyai buku LKS, sehingga jawaban bisa dicari ditiga buku referensi. Jika ada satu atau dua peserta didik yang berlebihan, itu sebagai bentuk reaksi dari setrategi pembelajaran yang baru. Dan itu sebagai bentuk kewajaran. Di pertemuan kedua ini juga ada kelompok yang mampu mempresentasikan hasil tugasnya, yaitu Tim yang dipimpin oleh Sadam. Diskusi pembelajaran berlangsung secara lancar, tertib, dan santun. Antusias peserta didik tidak menimbulkann kegaduhan, dan tetap dalam batas norma kesantunan yang sudah dimiliki oleh setiap peserta didik.

Dari proses pembelajaran yang berlangsung, motivasi peserta didik untuk bertanya sangat besar. Bahkan ada peserta didik yang berani menanyakan di luar materi pembelajaran. Untuk hasil belajar peserta didik pada Siklus I belum menunjukkan peningkatan. yang signifikan dari pre tes. Dari 32 peserta didik, ada 18 peserta didik yang nilainya di atas KKM. Dengan persentase 56,25 \%. Sudah melebihi $50 \%$. Tetapi secara rerata kelas masih minim. Selanjutnya untuk Siklus II ada peningkatan hasil belajar peserta didik. Dari 32 peserta didik, ada 29 yang berhasil memperoleh nilai di atas KKM. Sekitar 90,63\%. Kenaikannya sangat 
signifikan dari hasil belajar Siklus I ke Siklus II. Setidaknya dengan penggunaan model pembelajaran kooperatif type jigsaw ini, peserta didik kelas VIII-I menunjukkan peningkatan dalam prestasi belajar.

\section{KESIMPULAN}

Berdasarkan hasil penelitian dan pembahasan diperoleh kesimpulan bahwa secara umum terdapat peningkatan interaksi siswa dari siklus I ( $8809 \%$ ) menjadi 91, $63 \%$ pada siklus ke II . Peningkatan terjadi pada saat siswa berada di dalam kelompok Asal (apersepsi) $88,13 \%$ pada siklus I dan $93,75 \%$ pada siklus II dan pada saat siswa berada di dalam kelompok Asal (diskusi) yaitu 83,13\% (siklus I) menjadi 93,13\% (siklus II). Namun ada ada penurunan interaksi siswa pada saat berada di dalam kelompok Ahli.

Interaksi siswa dengan guru secara umum juga mengalami peningkatan sama halnya dengan interaksi antar siswa, namun persentasenya sangat kecil. Respon siswa terhadap pelaksanaan pembelajaran kooperatif tipe jigsaw sangat positip, hal ini ditunjukkan dengan antusiasme siswa dalam kegiatan pembelajaran, saling memberi informasi dan bekerjasama saat diskusi serta setiap siswa memberikan kesempatan kepada rekannya yang lain untuk aktif di kelompoknya.

Intraksi siswa dengan bahan ajar menunjukkan intraksi yang baik nampak dari analis video, terlihat dari keatifan siswa mengerjakan LKS dan mengisi jawaban pertanyaan. Hal ini juga nampak dari laporan observer saat refleksi.

Berikut diajukan beberapa saran berdasarkan penelitian yang dilakukan, terutama bagi guru bahwa pembelajaran kooperatif tipe jigsaw dapat dijadikan salah satu alternatif model pembelajaran yang dapat menciptakan suasana belajar yang menyenangkan bagi siswa dan dapat meningkatkan prestasi siswa. Dengan ditunjuknya Tim Ahli dalam kelompok, guru memberikan pembelajaran kepada siswa untuk mengorganisir sebuah kelompok kecil dalam menyelesaikan sebuah tugas bersama. Bagi Peneliti yang Lain. Dapat dipakai untuk penelitian yang berhubungan dengan hubungan sikap sosial yang terjadi di masyarakat.

\section{DAFTAR PUSTAKA}

Bambang Subali. 2008. Latihan dan Bimbingan Penelitian Tindakan Kelas Model Kemnis dan Mc Tagart. staff.uny.ac.id

David W Johnson, Roger T Johnson. (1999). Making cooperative learning work. Theory into practice 38(2),76-73

Elliot Aronson. 2002. Building empathy, compassion, and achievement in the jigsaw classroom, Improving academic achievement.

Jean Pieget. 2013. Teori Perkembangan Kognitif. SA Mu'min-AL-TA'DIB: Jurnal Kajian Imu Kependidikan 2013. ejournal.iainkendari.ac.id

Kementerian Agama Republik Indonesia. 2020. Al-Qur'an dan Terjemahannya. Jakarta Selatan, PT Pantja Cemerlang.

Kurniawati, S. 2006. Pengaruh Pembelajaran Kooperatif Tipe Jigsaw Terhadap Hasil Belajar Siswa Terhadap Mata Pelajaran Geografi Di SMAN 15 Bandung. Skripsi UPI:tidak diterbitkan.

Lie Anita. 2007. Cooperative Learning : Mempraktikkan Cooperative Learning di RuangRuang Kelas. Jakarta, Grasindo.

LPTK Fakultas Tarbiyah IAIN Antasari Banjarmasin. 2012. Diktat Pendalaman Materi Pendidikan Agama Islam Sekolah Menengah Pertama.

Rustaman et. Al. (2005). Perkembangan penelitian pembelajaran berbasis inkuiri dalam pendidikan sains. file.upi.edu. 